
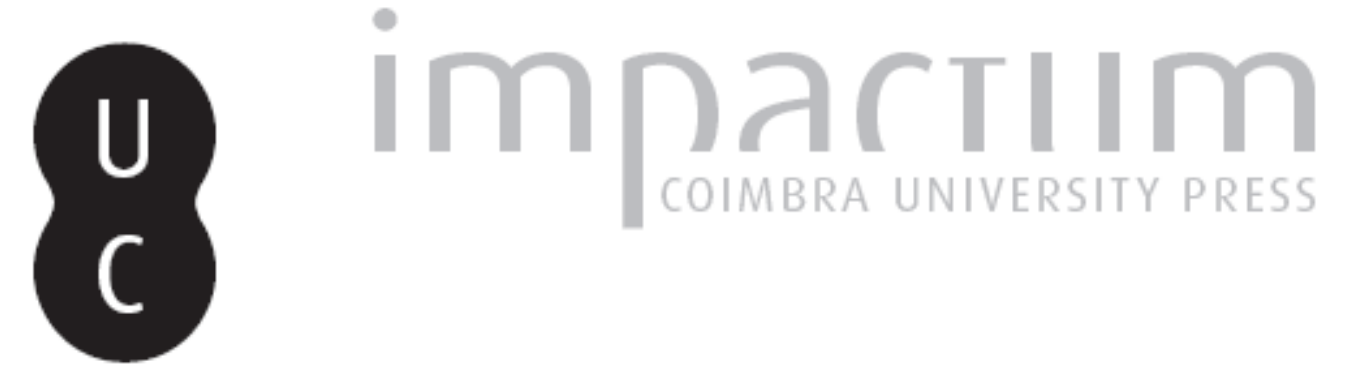

A configuração da forma: o belo como categoria transversal

Autor(es): $\quad$ Gomes, Helder

Publicado por: Faculdade de Letras da Universidade de Coimbra, Instituto de Estudos Filosóficos

URL persistente:

URI:http://hdl.handle.net/10316.2/33381

DOI:

DOI:http://dx.doi.org/10.14195/0872-0851_34_3

Accessed : $\quad$ 26-Apr-2023 11:16:30

A navegação consulta e descarregamento dos títulos inseridos nas Bibliotecas Digitais UC Digitalis, UC Pombalina e UC Impactum, pressupõem a aceitação plena e sem reservas dos Termos e Condições de Uso destas Bibliotecas Digitais, disponíveis em https://digitalis.uc.pt/pt-pt/termos.

Conforme exposto nos referidos Termos e Condições de Uso, o descarregamento de títulos de acesso restrito requer uma licença válida de autorização devendo o utilizador aceder ao(s) documento(s) a partir de um endereço de IP da instituição detentora da supramencionada licença.

Ao utilizador é apenas permitido o descarregamento para uso pessoal, pelo que o emprego do(s) título(s) descarregado(s) para outro fim, designadamente comercial, carece de autorização do respetivo autor ou editor da obra.

Na medida em que todas as obras da UC Digitalis se encontram protegidas pelo Código do Direito de Autor e Direitos Conexos e demais legislação aplicável, toda a cópia, parcial ou total, deste documento, nos casos em que é legalmente admitida, deverá conter ou fazer-se acompanhar por este aviso.

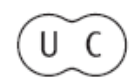




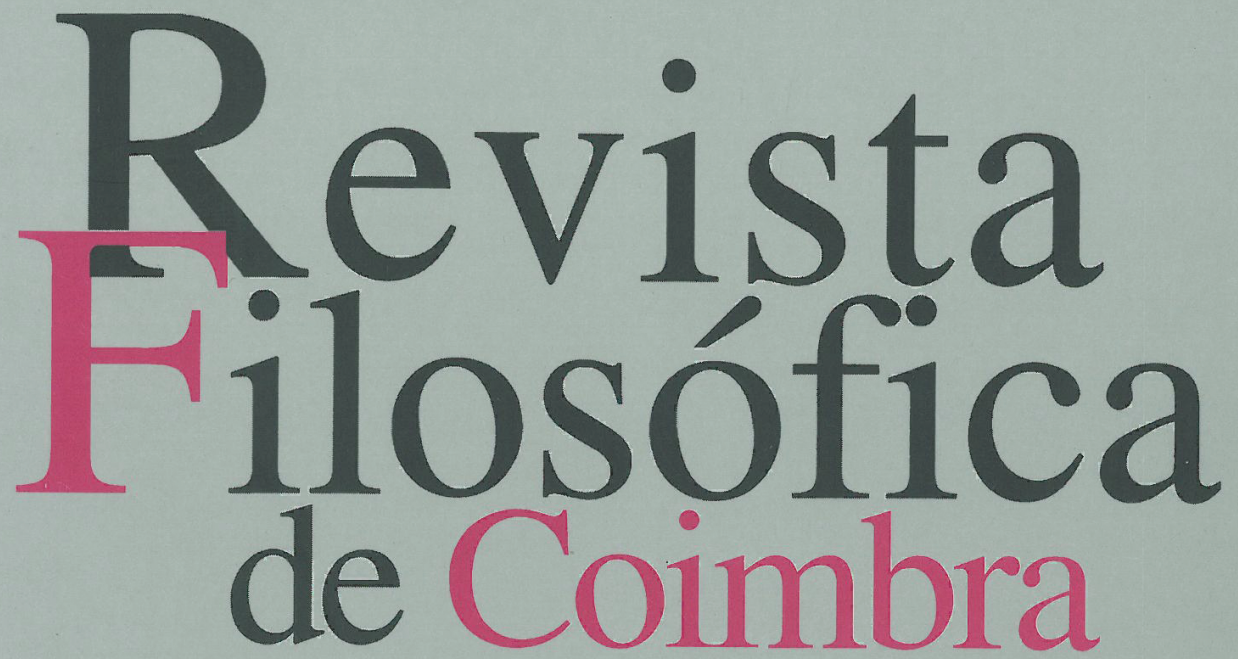

vol.17 | n.34 | 2008

José Reis

Manuel Moreira da Silva Helder Gomes

Filipe P. S. M. Menezes Edmundo Balsemão Maria João Silveirinha Luís António Umbelino Cláudio Alexandre S. Carvalho Armindo dos Santos Ana Isabel Boura Regina Queiroz Dulce Morgado Neves 


\section{A CONFIGURAÇÃO DA FORMA: O BELO COMO CATEGORIA TRANSVERSAL}

HELDER GOMES

(Faculdade de Belas Artes da Universidade do Porto)

Nas primeiras páginas de Os Cadernos de Malte Laurids Brigge, de Rainer Maria Rilke, e como parte de um movimento reflexivo que conduz o protagonista através das ruas de Paris de princípios do século XX, este afirma:

«Aprendo a ver. Não sei porquê, tudo penetra mais fundo em mim e não pára no lugar onde até agora acabava sempre. Tenho um interior de que não sabia. Tudo lá vai dar agora. Não sei o que ali acontece.»

E mais adiante:

«Já disse? Aprendo a ver. Sim, estou a começar. Ainda vai mal. Mas vou aproveitar o meu tempo». ${ }^{1}$

Este é um texto que se pode considerar herdeiro dos "romances de formação" do século XIX. Ao longo de uma narrativa construída entre o presente e a remissão para um passado fundador, assistimos a um movimento de constituição do sujeito como entidade reflexivamente consciente de si e consciente dos limites dessa mesma consciência. A aprendizagem do olhar é aqui parte de um processo de aprendizagem do eu e tem a paisagem urbana como espaço privilegiado de mediação. Mas esta é, ainda, uma aprendizagem que aceita o olhar dos artistas como mediadores de referência, seja o olhar do poeta, como Baudelaire, sejam os da escrita, ou os da modelação plástica da percepção sensível, aí representada pelas tapeçarias renascentistas do conjunto La Dame à la Licorne. A percepção do mundo pela mediação da arte é parte de um processo de formação da percepção.

\footnotetext{
${ }^{1}$ Rainer Maria Rilke, Os Cadernos de Malte Laurids Brigge,Trad. Paulo Quintela, O Oiro do Dia, Porto, 1983, p. 30, 31.
} 
A questão que se nos coloca hoje, sensivelmente um século após a escrita daquele texto, é a de saber quais as figuras privilegiadas no processo de formação do olhar contemporâneo: o que é que significaria, hoje, aprender a ver, e quais os principais instrumentos de mediação da percepção. No olhar de Rilke, a meio caminho entre uma herança romântica e o Modernismo nascente, inscreve-se ainda a convicção de que a arte pode constituir uma via de acesso privilegiada à percepção do real. Esta é hoje uma perspectiva que, não obstante o sucesso mediático da chamada "arte contemporânea", talvez já não seja sustentável.

Desta questão decorrerá uma outra: quais as consequências para a percepção subjectiva de índole estética e para o quadro de valores que a enquadram - nomeadamente para a categoria do belo - da perda de centralidade simbólica da arte, ou pelo menos daquelas manifestações que se enquadram no paradigma das belas-artes como produtoras privilegiadas de experiências estéticas de ordem visual?

Pelo menos desde do Renascimento e até ao século XX, e segundo diferentes hierarquias (de Vasari, de Hegel, de Clement Greenberg; etc.), às artes era concedido um lugar de formação do olhar, e de espaço privilegiado de experiência do belo. Independentemente da diversidade das caracterizações definidoras, as artes eram entendidas quer como ocasião e objecto, quer como modelo de uma relação com o mundo que tinha no belo o ponto óptimo de equilíbrio entre a percepção subjectiva e o dado exterior. Tratava-se de um processo de formação da percepção, fosse através da modelação do quadro de valores, fosse através da formação do imaginário; isto é, através da configuração formal daquilo que em cada momento era expectável como optimização potencial da experiência concreta. A arte dava a ver: ao mesmo tempo que designava o que ver, ensinava a ver e sugeria o quadro de valores susceptível de avaliar o sucesso da experiência.

O lugar da arte foi, nas sociedades contemporâneas, ocupado por todo um conjunto de práticas e experiências para-artísticas que, prescindindo da centralidade simbólica das belas-artes, moldam a experiência visual. Acompanhando a emergência de uma forte cultura popular urbana (uma cultura de massas), o centro de gravidade da produção do imaginário deslocou-se da esfera da experiência subjectiva como experiência privada para um espaço de produção ou recepção predominantemente público. Por exemplo, e numa acepção muito ampla, que inclui tanto a vivência efectiva do espaço como as experiências predominantemente representacionais (o vídeo, o espaço virtual, etc.), a paisagem contemporânea é hoje crescentemente moldada pelas chamadas artes menores: design gráfico, design de produto, publicidade, etc. Tal decorre de um movimento de conquista progressiva do espaço cultural por esses domínios e de um 
processo de recuo sobre si mesmas das práticas artísticas tradicionais. Investindo numa esfera predominantemente conceptual ou semântica, a arte contemporânea talvez tenha prescindido do papel de modeladora da experiência estética enquanto experiência sensível. Neste sentido, pensar a presença da categoria do belo na contemporaneidade implica pensar quais as experiências ou linguagens privilegiadas no processo de formação da experiência de percepção subjectiva.

Partamos da seguinte pergunta: será que, herdeiras relutantes da tradição das belas-artes, as artes ainda são belas?

Esta é uma pergunta à qual não se pretende aqui fornecer uma resposta. A questão de saber se as artes ainda são belas funciona neste texto como um indício negativo da actualidade da categoria de belo ao nível das artes contemporâneas, como constatação retórica de um movimento de desvinculação entre a categoria de belo e um conjunto de práticas e linguagens artísticas de ordem visual, sobretudo aquelas que correspondem às disciplinas tradicionalmente cobertas pela designação de belas-artes.

Não me proponho dar resposta a essa questão, antes do mais porque esse não é o tema em análise e, sobretudo, porque tal exigiria uma ampla abordagem historico-crítica que mostrasse como, ao longo dos últimos séculos, as práticas artísticas se foram desvinculando do belo como categoria de referência. Bastará que procedamos a uma breve contextualização. Num primeiro momento, a arte moderna, segundo um ideal de purificação legível a partir da noção de "arte pela arte", procedeu no decurso do século XX a um estreitamento das funcionalidades da obra de arte, centrando-a em dimensões preferencialmente estéticas. Evidentemente que esta pretensão à pureza não significava que, de facto, tais representações fossem unifuncionais: por mais que se pretenda pura, uma obra de arte cumpre, para além da função imediatamente estética, funções de ordem económica, social, política, etc. Tal significava, sim, que prevaleceu uma tendência sustentada de redução da esfera de acção das práticas artísticas, as quais, de um modo mais ou menos consciente e voluntário, prescindiram de algumas das suas valências para se centrarem numa investigação dos seus limites plásticos e conceptuais. Se a questão do belo constituiu ainda um problema central da estética moderna - senão de um modo positivo, pelo menos de um modo negativo, enquanto categoria capaz de referenciar o centro, definindo assim as margens de uma tradição e de um quadro de valores-, ela cedeu lugar, na segunda metade do século XX e como resposta à transformação do seu objecto, à questão mais restrita da natureza da arte. Em diferentes formulações ("quando há arte?", segundo a formulação de Nelson Goodman, "o que distingue a arte da realidade", segundo Arthur C. Danto, etc.), a questão da natureza da arte substituiu na reflexão estética a questão dos valores, nomeadamente a do belo. 
Sendo possível situar no Romantismo as origens deste movimento de desvinculação, ele será agudizado com a arte moderna e extremado nas últimas décadas do século XX. Se as artes já não são belas, não o são, antes do mais, porque a própria categoria de belo se terá revelado como restritiva na produção de representações predominantemente subordinadas a outras categorias: experimentação, crítica, etc. Este processo é sobretudo função de uma consciente e gradual radicalização da investigação criativa no interior das diferentes linguagens da arte que as conduziu até ao questionamento da sua própria identidade, e corresponde, sobretudo, ao privilégio de uma noção de produção artística menos imediatamente dirigida à modelação formal das suas linguagens. Este é um movimento exemplarmente pensado por Theodor Adorno ao nível da arte moderna e cujas premissas serão subvertidas pelo próprio processo: onde Adorno afirmava a arte moderna como lugar de construção de uma relação com o real passível de escapar às aporias de uma restritiva noção de racionalidade, a arte contemporânea parece, no aprofundar da mesma postura crítica, ter desembocado numa noção unidimensional da experiência estética: a dimensão semântica.

$\mathrm{Na}$ sequência de tendências que remontam ao início do século, a última metade do século $\mathrm{XX}$ assistiu ao que podemos designar como um devir-conceptual das práticas artísticas: uma transferência do investimento de produção artística da dimensão formal para a dimensão semântica das obras. Este devir-conceptual terá colocado em causa a função da arte enquanto lugar de formação e de mediação da experiência subjectiva visual, delegando para outros domínios a modelação da experiência estética enquanto percepção subjectiva de dados sensíveis. Se em parte esta é uma temática onde se cruzam a teoria da arte e a estética, a este processo subjazem questões de ordem estética de grande relevância. Não porque a estética enquanto disciplina tenha de se subordinar à prática artística imediata, ajustando-se de um modo reflexo aos movimentos e tendências artísticas do momento, mas porque as recentes transformações da produção artística revelaram como contingentes e eventualmente acessórios alguns dos predicados tidos por definidores da experiência estética. Uma vez que as artes visuais questionam a natureza estética (isto é, sensível) da sua relação com o real, preterindo-a a favor da dimensão conceptual, importa saber qual o lugar da percepção sensível na relação do sujeito com as construções culturais.

É manifesto o modo como, desde o Renascimento e não obstante a recorrente reivindicação de uma natureza intelectual, as artes plásticas se constituíram através de procedimentos de investigação plástica e formal, implicando um saber fazer e um saber percepcionar de ordem não exclusiva mas necessariamente sensível. Se as belas-artes recolhiam a sua 
designação sobretudo da sua capacidade de produção de representações visualmente apreensíveis e formalmente aperfeiçoadas, a transferência das preocupações artísticas para questões de ordem preferencialmente conceptual conduziu ao seu distanciamento face a categorias que derivavam de uma apreensão necessariamente formal das realidades culturais, como é o caso da categoria do belo. Simultaneamente, assistiu-se à afirmação da relação de interpretação de conteúdos semânticos como modelo privilegiado de recepção e experiência das obras de arte. A suposição de que à obra subjaz um "sentido" de ordem conceptual ou conceptualmente apreensível cresceu na mesma proporção em que, num movimento identificado por Adorno, a arte parecia subtrair-se voluntariamente a qualquer sentido imediato. $\mathrm{O}$ resultado foi a valorização quase exclusiva de uma relação com a obra dimensionada menos por princípios de ordem estética (enquanto derivados da percepção sensível), do que semânticos: mais do que ocasião para uma experiência estética, enquanto necessariamente sensível e subjectiva, as obras de arte tenderam a constituir-se como lugar de acesso a um sentido de cariz predominantemente lógico-verbal.

Em consequência, a arte contemporânea surge como não legível à luz de categorias como o belo ou só o é de um modo acessório. Não se trata aqui de afirmar a legibilidade da arte contemporânea à luz de categorias alternativas como o trágico, o grotesco, o sublime, ou outras; trata-se de constatar a estrita perda de relevância das categorias de matriz sensível. Muito daquilo que é proposto como arte na contemporaneidade poderá ser ou não belo, mas é-o ou não o é na mesma acepção em que é possível afirmar a beleza de um teorema, afirmando uma percepção de cariz estritamente reflexivo e sem que a beleza possa constituir critério de validade dessa representação. Naturalmente que seria possível pensar uma relação privilegiada com a categoria de belo, mesmo no interior desta deriva conceptual: a arte como produção de realidades representacionais dimensionadas sobretudo pela beleza formal poderia dar lugar à arte como produção de representações onde a beleza semântica (ou os belos conteúdos conceptuais, eventualmente desvinculados de critérínios de verdade) se constituísse como critério de optimização da produção e da recepção. Tal não é verificável ao nível da arte contemporânea porque, antes do mais, a exigência de radicalização e de experimentação torna difícil a formulação de propostas que apostem na relação de equilíbrio inerente à experiência do belo.

Importa sublinhar que não subjaz a esta análise nenhum pressuposto quanto a uma suposta natureza não conceptual das obras de arte. Evidentemente que nenhuma representação, e muito menos uma obra de arte, é semanticamente neutra; mas também será verdade que a pretensão 
de reduzir a experiência da obra a uma tentativa de produção e identificação de conteúdos semânticos tenderá a esquecer a especificidade cultural das próprias artes plásticas, nomeadamente a sua específica dimensão sensível. O sentido ou a significação ao nível das nossas experiências estéticas não pode ser simplesmente identificado com a dimensão lógico-verbal: não se trata de afirmar a não racionalidade das experiências estéticas, mas de as vincular a modos específicos da experiência do mundo. Trata-se, precisamente, daquilo que, num gesto estranhamente desfasado das tendências artísticas suas contemporâneas, Lyotard procura fazer na obra "Discours, Figure" com o conceito de figural 2: afirmar a existência de uma relação de apreensão de natureza especificamente estética, não redutível a estritos parâmetros de ordem lógico-verbal. Se pensadores como Panofsky demonstram a dimensão simbólica inerente à construção da experiência visual, tal não poderá ser entendido como legitimação da transformação de toda a experiência estética num pretexto para uma relação de "interpretação" numa acepção semântica, seja esta de natureza historicista, psicanalítica, política, sociológica ou outra. Isto significa que falar de "sentido" ao nível da experiência estética implica, sobretudo, colocar o problema no âmbito de uma relação de percepção de cariz subjectivo que não pode ser reduzida à estrita interpretação de conteúdos semânticos. Subordinar a experiência estética, enquanto relação de produção ou percepção subjectiva, a uma suposta dimensão conceptual traduzir-se-ia em subordiná-la a critérios de avaliação tendencialmente derivados do modelo da verdade formal: em cada momento o que estaria em causa não seria se uma dada experiência ou objecto poderiam ser tidos como belos (ou trágicos, ou horríveis, ou sublimes, ou kitsch, etc.), mas simplesmente se poderiam ser tidos como verdadeiros, ou, no mínimo, logicamente compreensíveis.

Ora, um modelo alternativo talvez possa ser fornecido pela experiência de realidades representacionais de natureza multifuncional. Diferentemente das representações intencionalmente produzidas como obras de arte, as realidades ou representações assumidamente multifuncionais não se apresentam à percepção subjectiva como necessariamente mediadas por uma relação de interpretação, cuja validade é susceptível

2 «Não se lê, não se ouve um quadro. Sentados à mesa, identificam-se, reconhecemse unidades linguísticas; de pé, perante a representação procuram-se acontecimentos plásticos. Libidinais. Que o mundo seja alguma coisa a ler significa de um modo brutal que um Outro, do outro lado, escreve alguma coisa que, com um bom ângulo de visão, eu poderia em princípio decifrar» - Jean-François Lyotard, Discours, Figure, Éditions Klincksiek, Paris, 1971, p. 10. 
de ser aferida segundo valores de verdade; dotadas de uma função ou de um sentido que se constitui em íntima relação com a sua configuração sensível, abrem-se à percepção como susceptíveis de uma relação estética, mesmo quando funcionalmente dirigidos a outros propósitos.

O questionamento da categoria do belo ao nível das obras de arte inscreve-se aqui: não é novo que a experiência estética possa ser pensada fora dos quadros da experiência estética como experiência das belasformas; em diferentes movimentos ou tendências artísticas, assistiu-se ao privilégio de outras categorias que não as do belo ou derivados. Por exemplo, no grotesco do século XVI e XVII, as formas poderiam não ser canonicamente perfeitas, sem que tal só por si significasse demérito artístico para a obra ou perda de intensidade estética para o espectador. Belas e atraentes, ou grotescas e repulsivas, ou grotescas e atraentes, estamos, em qualquer dos casos, perante representações susceptíveis de serem apreendidas pela mediação da experiência sensível subjectiva do sujeito, e cujo valor seria, positiva ou negativamente, mensurável segundo parâmetros de prazer e seus derivados.

Aquilo que é novo ao nível de algumas práticas artísticas contemporâneas é a afirmação da eventual irrelevância artística de algumas das categorias estéticas mais próximas da percepção sensível; o que se faz questão já não é uma hipotética ofensa ao belo (ou ao horrível, ou ao sublime, etc.) como categoria decorrente do privilégio de uma apreensão sensível das obras de arte, (aquilo que kantianamente se designaria por gosto), mas a produção de realidades artísticas que se colocam, na sua definição, num plano de quase completa indiferença face a estas categorias da experiência sensível subjectiva.

Poderíamos, então, reformular a questão: em vez de "será que as artes ainda são belas?", assumir que as artes podem ou não ser belas, mas que a beleza (em positivo ou em negativo) não constitui um predicado necessário. Assim, poderíamos interrogarmo-nos, "por que é que as artes já não são (ou já não têm de ser) belas?" Também a esta questão não se pretende dar resposta. Ela apresenta-se aqui como indício de uma outra que, supondo-a enquanto questão, não lhe exige uma resposta: porque é que, não obstante a constatação da desvinculação entre arte e beleza, esta última prevalece como categoria privilegiada na relação entre o homem e o real? Traduzirá isto um irreversível desfasamento entre a arte e a experiência humana, implicando um estreitamento da produção artística na contemporaneidade? Ou significará, inversamente, o alargamento ao todo da experiência cultural de uma atenção estética anteriormente direccionada para a arte de um modo preferencial?; implicará, ainda, a perda do lugar de referência do artista como mediador da experiência sensível e como formador privilegiado da percepção e do gosto? 
Optemos pela segunda resposta como hipótese de trabalho: a desvinculação entre a percepção subjectiva de cariz sensível e a arte abre ao todo da experiência modelos de relação que anteriormente eram preferencialmente dirigidos para a arte. Ora, se arte pode não ser apreensível à luz da noção de gosto como correlato de uma experiência sensível privilegiada, isto significa que a relação do sujeito com o mundo a partir da experiência do gosto deverá ser pensada fora do privilégio simbólico concedido pela Modernidade à arte enquanto lugar de mediação ou de formação da percepção. Assim, se a obra de arte supõe a existência de uma relação dual entre um sujeito produtor e um número indefinido de receptores potenciais, a relação estética que a contemporaneidade abre deve, antes do mais, ser pensada a partir do movimento de retirada do autor como sujeito privilegiado desta relação: quer do autor enquanto instância de fundamentação do sentido ou realidade da experiência, quer do autor enquanto produtor de realidades representacionais simbolicamente privilegiadas (as obras de arte).

Podemos entender a produção de uma obra de arte como a produção de um condicionamento intencional da experiência do espectador; se perspectivada a partir do espectador, a experiência da obra de arte surgirá, correspondentemente, como a aceitação atencional da proposta de condicionamento produzida pelo autor ou autores. Neste sentido, a acção do produtor surge como a formulação de uma proposta de experiência susceptível de ser percorrida pelo receptor: quer se trate de artes plásticas, de música ou de literatura, as propostas artísticas implicam a predefinição de um percurso mais ou menos determinado, mas que nunca o é em absoluto, como tendem a ser, por exemplo, os enunciados científicos, ou os enunciados de cariz religioso; as propostas artísticas estão constitutivamente abertas ao desvio, à inversão, ao abandono.

A existência em algumas realidades representacionais específicas da figura do autor como produtor intencionalmente consciente de condicionamentos não exige que toda a experiência da realidade perspectivada a partir de um olhar estético seja suportada pela existência de um autor e de uma intencionalidade autoral como sua condição: o investimento estético do espectador em realidades culturais multifuncionais (nas quais a função ou valência estética é secundária ou não intencionalmente determinada pelos seus produtores), assim como em realidades naturais não antropicamente transformadas, mostra que a experiência estética pode prescindir da figura do autor e da existência de um movimento consciente de condicionamento da experiência do receptor. Neste sentido, a valorização da dimensão constituinte da atencionalidade estética não é apenas uma exigência que decorra do desenvolvimento das práticas artísticas modernas e contemporâneas (lembremos a modelar afirmação de Marcel Duchamp, 
segundo o qual "são os observadores que fazem os quadros"3"), mas uma exigência da própria relação do sujeito com o real a partir da sua dimensão estética. Parte significativa do investimento da experiência estética não resulta de resposta a condicionamentos volitivamente determinados por um dado autor e conscientemente aceites pelo espectador, mas traduz, ele mesmo, um movimento de constituição da realidade numa representação apreensível como esteticamente relevante. A formação do olhar do sujeito da experiência potencia a formatação das diferentes experiências numa perspectiva estética. Aprende-se a ver, aprende-se a gostar, e neste processo de aprendizagem, aprende-se a configurar o mundo como coisa susceptível de uma relação de cariz estético.

Se se entender que a especificidade cultural das diferentes práticas artísticas (das artes plásticas à dança, do cinema à fotografia, da música à literatura, etc.) reside na produção ou experiência de realidades representacionais cuja configuração formal é determinante na sua constituição como realidades semanticamente interpretáveis, tal implica reconhecer que a identidade da experiência estética exige uma relação de mediação que simultaneamente prende e remete o sujeito à e para além da estrita configuração formal do objecto. Assim, mais do que uma experiência de índole semântica, a experiência da obra de arte enquanto experiência estética é uma experiência de formação da percepção: aprende-se a ver, ouvir ou sentir, como resposta às exigências específicas de um dado objecto.

Nesta acepção, a experiência da obra de arte enquanto representação estética não é particularmente distinta da experiência de qualquer outra realidade representacional ou representacionalmente constituída: as competências adquiridas na experiência das obras de arte são transponíveis para outras experiências de percepção e estas, por sua vez, condicionam a experiência das obras. Aquilo que está em causa é uma relação com o real que é dimensionada a partir de uma percepção subjectiva que retira dessa subjectividade as condições da sua própria afirmação. Mas esta é uma subjectividade dimensionada por um constituinte e formador movimento de interacção com as próprias experiências. Estabelece-se com o mundo uma relação de percepção que supõe a existência de modelos de optimização da configuração formal de cada objecto e que exige do sujeito um permanente movimento de definição

3 «São os OBSERVADORES que fazem os quadros. Descobre-se hoje El Greco; o público pinta os seus quadros trezentos anos depois do seu autor em título» - Marcel Duchamp, Duchamp du Signe: Écrits, Flammarion, Paris, 1994, p. 247. 
das condições dessa optimização. Tal vem reafirmar a actualidade da estética enquanto axiologia da percepção subjectiva: se a atenção estética proporciona modos de percepcionar o real, produz também os quadros e critérios de avaliação do sucesso de determinadas experiências.

Um olhar mais céptico dirá que nada disto é novo, e que tudo ou quase tudo isto está em gérmen na estética kantiana, e não é senão consequência do nascimento da subjectividade moderna. Sem recusar o carácter fundador da crítica Kantiana, importa equacionar a relação entre o sujeito e a experiência estética a partir da possibilidade da perda do privilégio simbólico da arte como relação de mediação estética. Se Kant afirma a superioridade do belo natural sobre o belo artístico, afirma igualmente o artista (na figura do génio) como instrumento de mediação privilegiado dessa mesma beleza natural. Aquilo que a contemporaneidade oferece é, reiteradamente, a existência de experiências estéticas que prescindem da figura do autor. E não se trata aqui de invocar aqui o topos da morte do autor, mas de constatar um movimento de alargamento da relação estética a áreas da experiência onde as marcas de autoria (ou de autoridade estética e semântica), como correlatos de uma acção intencional, cedem lugar à dimensão constituinte da atencionalidade. As exigências de optimização da configuração das representações ultrapassaram largamente as fronteiras estritas das disciplinas artísticas canónicas. A percepção estética contemporânea forma-se preferencialmente a partir de realidades culturais de natureza multifuncional onde a valência estética é acessória ou de matriz não formalmente artística.

Admitindo que o artista desempenhou durante séculos o papel de mediador e de formador da percepção, qual é hoje a natureza desta relação de mediação? Mesmo sem as pretensões teleológicas de matriz hegeliana ou radicalismos perspectivísticos de cariz nietzschiano, sabemos que o ser humano tende a privilegiar as representações face à própria realidade; tendemos a privilegiar os constructos, quer como objecto de experiência, quer como instrumentos de mediação. Por exemplo, tendemos a preferir a representação pictórica (ou cinematográfica, ou televisiva, ou outra) da paisagem à própria paisagem; ou, no mínimo, a percepcionar sempre a paisagem através da sua formatação simbólica, fruto de um processo de formação no interior dos quadros de um dado contexto histórico-cultural. Se toda a experiência é, numa acepção genérica, construída - enquanto procede por uma manipulação física ou simbólica do seu objecto-, o privilégio das práticas de produção cultural associadas às belas-artes como experiências susceptíveis de produzirem ou de revelarem a experiência do belo prendeu-se, sobretudo, com a particular aptidão das suas linguagens para moldarem o objecto de experiência. Apesar da cultura 
contemporânea tornar esta questão mais premente, a natureza multifuncional da generalidade das nossas representações, associada ao carácter transversal das nossas experiências, permite afirmar que a formação da percepção estética sempre assumiu um carácter representacionalmente transversal, sendo excepcional o privilégio concedido às representações artísticas.

Terá sido a riqueza potencial de algumas linguagens que conduziu à sua primazia: por exemplo, do ponto de vista da sua complexidade e ductilidade potenciais, a escultura, enquanto modelação da pedra ou do bronze, é formalmente muito mais rica e perene do que a escultura enquanto topiária. Para além de considerações de ordem simbólica, como as que presidiram à autonomização das belas-artes como artes maiores face às restantes práticas de produção artesanal, foram as potencialidades formais destas linguagens (ou mediums) que permitiram a sua afirmação como experiências privilegiadas de formação da percepção. Este processo de formação é, tendencialmente, um processo de construção de modelos formais de reconhecimento e valoração estética do real.

Neste sentido, a experiência do belo surge como a produção ou a identificação da optimização das potencialidades de organização formal de uma dada realidade: a apreensão de um rosto como belo decorre, naturalmente, de condicionamentos culturais, históricos, de género, entre outros, mas em qualquer dos casos a apreensão da beleza num rosto traduz a identificação de um grau mais ou menos elevado de optimização das potencialidades formais de uma dada realidade ou linguagem. E tal é válido qualquer que seja o critério estrito usado: mesmo que prevaleçam critérios de ordem ética (e não estritamente estética), a caracterização de um gesto como belo não em função da sua organização formal, mas de um dado procedimento ético, coloca-nos ainda diante da sua caracterização como correspondendo a um elevado grau de organização de uma dada acção potencial.

Isto implica que é possível identificar no interior de cada realidade ou representação as condições de optimização da sua organização estética face ao contexto em que se inscreve. Esta é uma relação de apreensão que é relativa à formação do sujeito, à sua sensibilidade e à riqueza de dados disponíveis: ao nível da experiência estética, a definição dos critérios caminha a par do desenvolvimento dos objectos que lhes correspondem: a optimização da performance de um dado sujeito ou representação implica o aprofundamento do grau de exigência dos critérios que são aplicáveis a si e às experiências similares.

Ora, a deslocação e partilha com o todo das práticas culturais de uma atenção estética anteriormente dirigida ou moldada pela arte abrem a experiência estética a uma espécie de movimento de desregulação: a 
formação do olhar (ou da audição, etc.) já não se faz através de um implícito movimento de doação dos quadros de referência adentro dos quais um dado gesto ou movimento é entendido com válido. No interior da tradição das belas-artes, aprender a jogar significava simultaneamente aprender as regras do jogo e identificar quais as condições em que um dado movimento poderia ser entendido como bem sucedido. A sensibilidade contemporânea, ao transferir para a esfera pública a constituição das realidades como objectos de experiência estética, nem sempre fez acompanhar tal transferência da doação dos quadros de referência. Embora induzida pelos objectos, a modelação da experiência exige do receptor uma clara dimensão formadora. Uma vez que aprendizagem já não se faz a partir de mediadores privilegiados (ou porque estes estão ausentes ou porque prescindem da sua autoridade simbólica), cabe ao receptor a determinação do seu quadro de referência. E este quadro de referência constrói-se, na contemporaneidade, no movimento de interacção com realidades de natureza predominantemente multifuncional. É este o contexto em que hoje a percepção se forma: a percepção e os modelos de identificação e avaliação do sucesso das experiências constroem-se de um modo transversal e tendo por objecto realidades de natureza predominantemente multifuncional.

Neste sentido, poderíamos afirmar que a contemporaneidade revela o belo como categoria em larga medida objectiva; objectiva, enquanto objectual: apesar da dimensão constituinte da atencionalidade, é o objecto que sugere a formas privilegiadas da sua própria percepção. Não se trata aqui de contrariar nem a figura da atencionalidade como relação constituinte da experiência estética, nem a afirmação kantiana da subjectividade da experiência estética: qualquer que seja a objectividade do objecto da experiência estética, a relação de apreensão particular é sempre subjectiva, e é, igualmente, parte de um processo de constituição do objecto que verdadeiramente não lhe é nem anterior nem exterior. Mas isto não significa que a experiência do belo (ou de qualquer outra categoria esteticamente relevante) seja em absoluto subjectiva; não apenas ela assenta em dados empíricos supra subjectivamente partilháveis, como, sobretudo, ela tende, se aprofundada, a decorrer do domínio optimizado das potencialidades estéticas de um dado conjunto de linguagens e formas de corporização de representações. É nesta acepção que, a um primeiro nível, podemos caracterizar o belo como transversal: é culturalmente transversal porque, enquanto supõe o domínio de um conjunto de formas simbólicas formadoras da percepção, é susceptível de ser partilhado por diferentes sujeitos (não se esgotando, de facto, na estrita subjectividade). Retirando-lhe a exigência de universalidade, estamos aqui em território próximo da noção de sensus 
communis em Kant ${ }^{4}$. E é também transversal, porque o objecto da experiência que potencialmente o suscita é, em larga medida, independente da sua actualização por qualquer sujeito: por exemplo, a não existência de um espectador reflexivamente consciente não retira nada à beleza potencial das realidades naturais que se sucederam na Terra antes do aparecimento da espécie humana. Evidentemente que esta afirmação só é válida retrospectivamente e supõe a existência de um sujeito reflexivamente consciente, mas isto mesmo demonstra a ambígua característica da dependência das experiências estéticas de uma constituinte atencionalidade, e o carácter tendencialmente objectivo do belo.

É este duplo movimento de formação da sensibilidade e de reconhecimento e formação subjectiva da realidade enquanto objecto de experiência estética que podemos designar como configuração das formas; trata-se de um movimento reflexo que decorre tanto da existência de uma experiência susceptível de responder por um mais ou menos elevado grau de exigência, como da capacidade do sujeito para, activamente, a reconhecer atencionalmente. Neste sentido, é uma relação em absoluto gradativa que nunca é estritamente mensurável pela intensidade da apreciação subjectiva do espectador: se é na relação entre uma dada configuração formal e um dado conjunto de valores e expectativas do espectador que se constrói a experiência, basta que exista uma relação de adequação ou de equilíbrio aproximado entre a realidade que suscita ou é objecto da experiência e as exigências decorrentes das categorias subjectivas do sujeito para que tal relação possa ser entendida como intensamente satisfatória, mesmo que a um olhar exterior tal decorra apenas de um muito baixo grau de exigência por parte desse sujeito. Se o gosto é relativo, nesta acepção, ele deve admitir igualmente a sua natureza gradativa, constituindo esse o verdadeiro critério quer das propriedades estéticas de uma dada realidade ou representação, quer da riqueza perceptiva do sujeito: por um lado a capacidade que uma dada realidade ou representação tem para suportar um aumento de exigência perceptiva por parte de um sujeito ou comunidade de sujeitos, por outro, a capacidade que, fruto da sua formação (isto é, fruto de um trabalho partilhado de configuração do mundo), um sujeito, ou comunidade de sujeitos, tem para explorar as potencialidades estéticas de uma dada realidade, num movimento de interacção subjectiva, cultural e historicamente transversal.

${ }_{4}$ «or sensus communis (...) tem de se entender a ideia de um sentido comunitário, isto é, de uma faculdade de julgamento que, na sua reflexão, considera em pensamento (a priori) o modo de representação de todo o outro, como que para ater o seu juízo à inteira razão humana e assim escapar à ilusão que — a partir de condiçıes privadas subjectivas, as quais facilmente poderiam ser tomadas por objectivas - teriam influência prejudicial sobre o juízo» - I. Kant, Crítica da Faculdade do Juízo, trad. António Marques, Valério Rohden, Imprensa Nacional Casa da Moeda, Lisboa, 1998, 40, p. 196. 